\title{
War or Peace on the Rivers of South Asia?
}

\author{
Muhammad Imran Mehsud*1-2, Azam Jan ${ }^{3}$ \& Tariq Anwar Khan ${ }^{2-4}$
}

1. School of Politics \& International Relations, Quaid-e-Azam University, Islamabad, Pakistan.

2. Department of Political Science \& International Relations, Hazara University, Mansehra, Pakistan.

3. Department of Communication \& Media Studies, Hazara University, Mansehra, Pakistan.

4. Department of Political Science, Faculty of Social Sciences, University of Punjab, Lahore, Pakistan.

\begin{abstract}
The renowned water expert, John Briscoe, predicted a bleak future for India-Pakistan water relations across the Indus attributing it to Pakistan's downstream anxieties vis-à-vis upstream regional hegemon-India. Do the other co-riparian states of India share the same bleak future across the South Asian rivers of the Ganges, Brahmaputra, and Meghna or are the water relations across these rivers peaceful as compared to the Indus? To answer this question, this study first explores India-Pakistan water disputes on the Indus and then analyses India-Bangladesh water disputes on the Ganges and Brahmaputra, India-Nepal, India-Bhutan, and Pakistan-Afghanistan water relations. The methodology adopted for this study is descriptive, historical, and analytical in its nature. The study concludes that India has not only failed to adopt a conciliatory approach towards Pakistan on the Indus but has generated mistrust amongst other neighbouring countries over water sharing due to its hegemonic hydro-behaviour. It recommends that India should adopt a conciliatory approach to have peaceful relations across the rivers of South Asia.
\end{abstract}

Keywords: Water Wars, Water Disputes, Water for Peace, Indian Rivers, Pakistani Rivers, South Asian Rivers, Indus Rivers, Media Role in Water Crisis.

\section{Introduction}

An article titled "War or Peace on the Indus?" was published in daily The News International, Pakistan written by John Briscoe on April 3, 2010. The author was a Professor at Harvard University at that time who had worked on the water issues of South Asia for 35 years. When the Baglihar Dam dispute surfaced between India and Pakistan, Briscoe was Senior Water Advisor for the World Bank. The Bank played an important role in the appointment of the Neutral Expert (NE)- Raymond Lafitte-in 2005, who gave his verdict on the disputed dam in February 2007, largely in India's favour. Winner of the Stockholm Water Prize-the "Nobel Prize of Water"- the late professor Briscoe expressed his deep affection for the people of India and Pakistan but predicted a bleak future for water relations between the two riparians. He wrote in the stated article that, "I have deep affection for the people of both India and Pakistan and am dismayed by what I see as a looming train wreck on the Indus, with disastrous consequences for both countries."

Ten years after this article, Briscoe's prediction appears true as India-Pakistan water relations are mired in the choppy waters of the Indus. One of the major reasons he had hold responsible 
for the "looming train wreck on the Indus" was the Baglihar verdict of the NE. The verdict not only permitted India to construct a dam but robbed the Indus Water Treaty of its protective mechanisms against any malicious manipulation of the western rivers to the disadvantage of downstream Pakistan. As such, the NE's decision paved way for the execution of an Indian hydro-hegemony on the Indus. Analysis of the hydro politics of South Asia reveals that the bleak picture that Briscoe had portrayed not only still hold water for the Indus river but for the Brahmaputra-Ganges-Meghna river systems as well. Inspired from Briscoe's article, this research article is an attempt to analyse the Indian hydro-hegemony through analysing the India-centric water disputes across the river basins of the Indus, Brahmaputra, Ganges and Meghna. These river systems are shared by extra-regional states like China and Myanmar as well. However, this article focusses on the South Asian co-riparian states of India, Pakistan, Bangladesh, Nepal, Bhutan and Afghanistan.

This article has been divided into six major sections. The section one provides an overview of the theoretical and methodological approaches adopted for this study. The section two provides an insight into the India-Pakistan water disputes on the Indus. Section three analyses IndiaBangladesh water disputes on the Ganges and Brahmaputra. Section four discusses the IndiaNepal water relations. Section five discusses the India-Bhutan water cooperation which is a deviation from Indian policies towards Pakistan, Bangladesh and Nepal. Section six provides an insight into Pakistan-Afghanistan potential water crises which Pakistan finds motivated by Indian hydro hegemony.

\section{Methodological and Theoretical Approach}

The methodology adopted in this article is qualitative, descriptive and analytical. IndiaPakistan water relations are first analysed from the perspective of Indian hegemonic designs as pointed out in John Briscoe's article. The same point of view is further elaborated through providing evidences from literature available on the issue at hand. This study then discusses India-Bangladesh water relations, India-Nepal, India-Bhutan and Pakistan-Afghanistan in the same perspective as developed in the Briscoe's article. Both secondary and primary sources of data are employed to reach plausible conclusions. The secondary sources included magazine research articles, books, reports by NGOs, research institutes and think tanks. The primary resources included excerpts from the primary documents like the Indus Waters Treaty, the Ganges Water Treaty, etc. This study doesn't claim to be covering each and every aspect of the riparian relations across all the rivers of South Asia. The focus of this study is to identify any Indian hegemonic approach across the rivers of South Asia. Theoretically, the study is approached from the perspectives of the three dominant theoretical traditions of (neo)liberalism, constructivism and (neo)realism. However, since the study approached to analyse Indian hegemonic behaviour on the rivers of South Asia, therefore, the power imbalance perspective of neorealist church has been employed predominantly.

\section{India-Pakistan Water Disputes}

The partition of India into two sovereign states of Pakistan and India in 1947 paid little attention to the division of the Indus and its five tributaries- the Beas, Ravi, Chenab, Jhelum and Sutlej. Division on such lines was termed well by Gardner (2019) as "Indus watershed". The partition left the vast irrigation network of the Indus basin with Pakistan and the headwaters of the rivers feeding this irrigation network with upstream India. On $1^{\text {st }}$ April 948, the upper riparian India stemmed water flow from two canals flowing into Pakistan (Gulhati, 1973), a move to regulate 
water flow into Pakistan (Wasi, 2009). India adopted a bilateral and temporary approach to resolve the water dispute and an adhoc bilateral agreement-the Delhi Agreement-was reached on $4^{\text {th }}$ May 1948. Pakistan's authorities argued that the agreement was signed under duress and decided not to abide by it. It argued that India had tabled the document as a pre-condition to release water into the canals. Being well aware of the costs and coercive nature of bilateral approach with a stronger upstream rival riparian, Pakistan insisted on third party mediation to find a lasting solution for its quest for water security (Bhatti, 2020).

David E. Lilienthal, a senior American bureaucrat, visited India and Pakistan in February 1951 to assess the Kashmir dispute first-hand. He came to the conclusion that, "India and Pakistan are on the edge of war over which shall possess Kashmir - a fight the US might be forced to enter" (Lilienthal, 1951). To resolve the Kashmir dispute, he suggested the US to resolve the water dispute first. He was sanguine that the resolution of water dispute between the two riparians will ultimately lead to the resolution of the Kashmir dispute as well. The US' government apparatus asked the Word Bank to offer its good offices and resolve the Indus water dispute. The Bank's offer was accepted by both India and Pakistan. After nine years of protracted negotiations, the Indus Waters Treaty (IWT) came into existence on 19 September 1960 in Karachi.

The IWT divided the six major rivers of the Indus river system between India and Pakistan. It allocated the three eastern rivers- the Sutlej, the Beas and the Ravi- to India whereas the three western rivers-the Indus, the Chenab, and the Jhelum- to Pakistan. The Treaty permitted both the riparian restrictive rights to use each other's allocated rivers for agriculture, hydrogenation and other purposes which did not involve water storage or diversion (Indus Waters Treaty, 1960, Article III). However, such provisions of the Treaty were of little utility for Pakistan as no main river of the Indus river system originated within Pakistan and the country's irrigation depended mainly on the Indus (Pohl \& Schmeier, 2014). Keeping in view their rivalry, the IWT incorporated some safeguards against Indian structures India might design in future on the western rivers; the rivers allotted to Pakistan under the IWT. The Treaty also provided for a Permanent Indus Commission and a detailed dispute resolution mechanism as well (Indus Waters Treaty, 1960, Article VIII \& IX). If a problem was to arise out of water apportionment, it was first referred to the Permanent Indus Commission. In case of a disagreement, it was then referred to a NE appointed by the World Bank. In addition, the party could also engage a Court of Arbitration, depending on the nature of the points under dispute.

The IWT worked well for the first three decades of its existence. Some water disputes surfaced between India and Pakistan in the meanwhile but were resolved in accordance with the dispute resolution mechanism of the Treaty. The Treaty was applauded as a model treaty by many renowned political scientists including Stephen P. Cohen who stated that, "the Indus Waters Treaty is a model for future regional cooperation, especially on energy, environmental concerns, and even the management of the region's impressive water resources" (Cohen, 2005). However, by the turn of the present century, the Treaty began to drift towards hot waters. Some of the experts labelled the Indus Basin as the world's second most over-stressed aquifer (Buis $\&$ Wilson, 2015). The reasons for the stress in the Treaty were multiple. From the water supply perspective, climatic change and its implications for Himalayan glaciers and the monsoon patterns, and the excessive exploitation of groundwater in the basin resulted in water depletion (Jayaram, 2016) which proved to be a major challenge in the Indus Basin (Kugelman, 2016). From the water demand perspective, the demographic bulge in both India and Pakistan, and its spin off demand for more food, and the drive for modernization which speed up the drive for 
industrialization, resulted in enormous increase in water demand. The changing nature of lifestyles from simple living standards with simple foods and simple houses to complex protein foods and modern houses demanded incessant waters for drinking and sanitation, specially, in Pakistan (Amir \& Habib, 2015). The need for hydropower generation also played its due role in the water crisis.

However, one factor for the stress in the IWT was the fresh Indian drive for construction of hydel projects on the western rivers of Pakistan. On $24^{\text {th }}$ May 2003, the Indian Prime Minister Attal Bihari Vajpayee disclosed an 1150,000 Mega Watt (MW) initiative of constructing hydel power stations mostly on the western rivers. Primary Feasibility Reports of 162 new hydropower projects of $50000 \mathrm{MW}$ to be completed by 2017, was prepared and in the next decade to add $67000 \mathrm{MW}$ was further planned (Khalid, 2010). Out of these total projects, Pakistan raised objections on 67 of the Indian projects as they were claimed by Pakistan to be in violation of the IWT. Pakistan's apprehensions against few of the Indian projects objected by Pakistan were as follows:

\subsection{Wullar Barrage/Tulbul Navigational Project}

Located on river Jhelum, near Sopore in the Indian held Kashmir, construction on the Wullar barrage project started in 1984. Pakistan objected on the project and construction was stopped in 1987. Pakistan objected the projects on the grounds that the project did not confirm to the restrictive safeguards that were hardwired into the Treaty to restrict the potential of Indian projects to control the flow of water to the disadvantage of downstream Pakistan. Moreover, Pakistan charged that the project's storage capacity would harm the canal system of Pakistan as it would affect the volume of daily water flow. India defended the project on the grounds that the barrage would just regulate water flow. It asserted that the project would store water on temporary basis and will only extend the period of water availability so as to make it possible for navigation for a longer period. However, the Indian argument was considered weak and it halted the work on the project. In the wake of the Baglihar verdict of 2007, India attempted to negotiate the project afresh in 2008.

\subsection{The Baglihar Dam}

Located in the southern Doda district in the Indian held Kashmir over the Chenab, Baglihar dam is a 450-MW hydroelectric project which has the potential to expand to $900 \mathrm{MW}$. It was conceived in 1992, approved in 1996 and construction on the project started in 1999. Pakistan objected that the project will store and divert the waters of the Chenab and is, thus, in violation of the restrictive safeguards of the IWT. The dispute prolonged until May 2005, when on Pakistan's appeal the NE-Raymond Lafitte-was appointed by the World Bank. On 12 February 2007, the NE gave his verdict with the following recommendations as; its storage be reduced from 37.5 million cubic meters to 32.45 million cubic meters, the free board be reduced from 3 meters to 1.5 meters, the water intake be increased by 3 meters and the gated spillways were to be accepted as in accordance with the Treaty (Uprety \& Salman, 2011).

The decision was accepted by Pakistan as the decision of the NE was final and not appealable at any other court (Indus Waters Treaty, 1960, Annexure F, Paragraph 11). Interestingly, both the nations proclaimed victory to be on their side. However, Pakistan had to realize the repercussions of the Baglihar verdict later. "This vulnerability was driven home," as John Briscoe had maintained in his stated article, "when India chose to fill Baglihar exactly at the 
time when it would impose maximum harm on farmers in downstream Pakistan." India carried on its construction and its first phase was completed by 10 October 2008. It was thus the Baglihar verdict ripped the IWT off of the protective safeguards its architects had incorporated vis-a-vis Indian projects on the western rivers in the Treaty. To elaborate this point further, Briscoe stated in the same article that, "But following Baglihar is a veritable caravan of Indian projects - Kishanganga, Sawalkot, Pakuldul, Bursar, Dal Huste, Gyspa ... The cumulative live storage will be large, giving India an unquestioned capacity to have major impact on the timing of flows into Pakistan."

\subsection{The Kishanganga Dam}

Kishanganga dam is a $330 \mathrm{MW}$ project. It is located in Gurez valley, near Bandipora in the Indian held Kashmir, on the river called Neelum River in Pakistan, and Kishanganga in India. India began construction on the project in 2007 but was halted temporarily by the Court of Arbitration in 2011 due to Pakistan's objections. Pakistan objected that the project involved diversion of waters from a western river tributary-the Neelam River-to the Wullar Lake and was in violation of the IWT. It stressed that such a diversion would adversely affect some of Pakistan's hydro power projects on the river Neelum especially the Neelum-Jhelum project. Moreover, Pakistan also asserted that the Indian project would also displace the resident of its locality by submerging a major portion of the Gurez valley. However, the December 2013 decision of the Court of Arbitration constituted in the context of Kishanganga dispute legitimized the project, which was added as another project to the "veritable caravan of Indian projects" on the western rivers.

With the completion, operationalization and legitimization of even half of its planned 162 projects, India could not only play havoc with the agro-based economy of Pakistan but could also use the same as serious strategic threat to Pakistan. Military strategists are well aware of the role of water bodies in the warfare. It was under this strategic value of water bodies that Pakistan constructed a series of canals on its eastern borders after the IWT was signed in 1960. The canals not only help divert waters from the western rivers to the areas previously irrigated by the eastern rivers, but also serve as a kind of "Maginot Line" against Indian aggression. Armed with the weapons of water through its planned dams, India could release waters into the downstream rivers, the flooding of which could affect the strategic maneuverability of Pakistan armed forces. Similarly, India could also withhold the waters from the strategic canals on Pakistan's eastern borders and render the canals obsolete against any Indian aggression. History is witness to the fact that these defense canals were the biggest hurdle for the Indian forces to cross in the war of 1965 (Sharif, 2008). Moreover, during the India-Pakistan military standoff of 2002, Pakistan released waters into these canals to convert them into "trenches" against possible Indian aggression.

\section{India-Bangladesh Water Disputes}

Including the Ganges and the Brahmaputra, India and Bangladesh share 54 trans-boundary rivers. Being downstream and at lower elevation to India, Bangladesh is exposed to flood in the monsoon season and to drought in the lean period from January to May, resulting in IndiaBangladesh friction on water management. Moreover, India is constructing barrages, canals and irrigation systems on ten of the major transboundary rivers to divert and use its waters. However, the water projects in the Brahmaputra and Ganges basins generated a great deal of hydro-political tensions between the two neighbours, particularly the projects India developed 
unilaterally (Scott et al., 2019). In addition to the quantity issues, water quality issues also added into this complex water sharing between the two riparians. The upstream industrial, sanitation, and agricultural wastes polluted waters flowing into the downstream Bangladesh. Following is a detail of Indo-Bangladesh water disputes.

\subsection{Ganges Water Dispute/Farakha Barrage}

Announced in 1951, construction on the Farakha barrage started in 1961 and became operational in 1975. It is located at Farakha (West Bengal), 11 miles from East Pakistan (which became Bangladesh after its independence from West Pakistan in 1971) across the Ganges. The barrage diverted Ganges water through the Baghirati-Hoogli river system to flush the sedimentations at the port of Calcutta. The barrage served as the most important irritant between India and Pakistan and after 1971 between India and Bangladesh (Uprety \& Salman, 2011). The Indian side argued that its construction was necessary to make the Calcutta port navigable. Bangladesh bemoaned that the barrage had adverse downstream effects. It claimed that the project effected Bangladesh's fisheries, agriculture, and the navigation of the Ganges in addition to affecting the quality of water for irrigation and domestic use by creating salinity and pollution downstream.

The actual problem lied with the flow of the Ganges during the lean period of April and May where the flow of the Ganga decreased to 5,500 cusec, out of which India claimed that it needed 4,400 cusec of water to flush the port of Calcutta. Therefore, the main point of dispute was the difference in strategies of augmenting the flow of water during the lean months so as to meet the demands of both the riparian (Sood \& Mathukumalli, 2011). From 1960 till 1970, ten meetings were held between the officials of the two states, but to no avail. When East Pakistan became Bangladesh in 1971, India and Bangladesh established the Joint Rivers Commission in 1972. However, before reaching an agreement, India operationalised the barrage in 1975 without consulting downstream Bangladesh. Consequently, in 1976, Bangladesh registered a complaint against Indian unilateral hydro-behaviour to the UN General Assembly. The Assembly asked both the parties to meet at ministerial level and resolve the dispute.

Employing the same bilateral approach, which it had adopted towards Pakistan's post-partition quest for water security, India engaged in negotiations with Bangladesh but resorted to ambiguous and temporary arrangements. Consequently, in 1977, India and Bangladesh signed an agreement, the Ganges Water Agreement. The agreement was for five years requiring both the states to pursue a long-term solution to the problem. After the lapse of the five-year period, two Memorandums of Understanding (MOUs) were signed, the first one in 1982, and the second one in 1985, each for two years. Each MOU asked both the signatories to distribute the waters on temporary basis until a permanent solution was reached. From 1988 onward, no further agreements were made, and India drew water for its use, unilaterally (Sood \& Mathukumalli, 2011). Bangladesh registered another complaint with the Commonwealth Summit in 1993 and again with the UN General Assembly in 1995. Bangladesh's repeated efforts of referring the case to international multilateral bodies represented its desire to internationalize the dispute and resolve the dispute through multilateral hydro-diplomacy. However, India kept on harping on the same bilateral and temporary approach until the Ganges River Treaty was signed on December 12, 1996.

The Ganges River Treaty, signed on for 30 years, provided for the Ganges water distribution between India and Bangladesh from $1^{\text {st }}$ January to $31^{\text {st }}$ May each year. In case of decrease of 
water table below 50,000 cusecs, the two riparians were to consult each other. If a dispute was to arise out of water apportionment, a joint committee consisting of the representatives of the two nations was to be consulted. If still unresolved, the dispute was to be put before the Joint River Commission which according to critics had only an authority of consultation. In case of failure of the Commission to resolve the dispute, both the states had to take the dispute to the governments of the two states. The treaty did not provide for any mechanism in case the two governments failed to resolve the dispute. In addition, the treaty also stressed upon reaching agreements on the remaining 53 rivers (Uprety \& Salman, 2011). However, no productive agreement was reached in this regard between the two states and no single agreement was arrived at on the rest of the rivers. Moreover, the actual problem of how to augment the flow of water during the lean period in the Ganges still persisted.

\subsection{Teesta River}

The Teesta river is the fourth largest river of Bangladesh after the Ganges, the Brahmaputra and the Meghna. It siphons-off waters from the Cholamo Lake in the Himalayas Mountain in India. On its way toward the west Bengal, the river is fed by many small rivers and is also joined by Rangeet river and then it enters Bangladesh. This river too remained disputed between the two riparians. India adopted the traditional bilateral and temporary approach to resolve the dispute on this river as well. In 1983, an adhoc agreement was reached by the Joint River Commission of the two states, to allocate the rivers water on temporary basis. Bangladesh received 36 percent, India 39 percent and 25 percent of the waters were left for the flow of the river. However, the treaty was never put into action in its true spirit.

India stressed that scientific studies be completed before reaching a permanent agreement on allocation of the waters of the river Teesta. Meanwhile, India built a number of run-of-the-river hydropower projects and a diversion barrage on the Teesta River which had negative implications for downstream Bangladesh. Some agreements were reached between the two riparians in 1996 and 1998, but Bangladesh objected that India did not implement the agreements in letter and spirit (Scott et al., 2019). In 1998, Bangladesh also constructed its Teesta barrage downstream. Bangladesh objected that Indian projects were diverting more water, which was adversely affecting the Teesta barrage and its other irrigation project downstream. In 2004, Bangladesh changed its earlier stance reached in the 1983 adhoc agreement by stressing that 39 percent water be allocated to India, 36 percent to Bangladesh and 10 percent for the flow of the river and the rest be allotted according to the proportion. India insisted upon the completion of scientific studies first.

\subsection{The National River Linking Project}

In 2002, the Indian government announced the world's largest inter-basin water transferring project involving linking of 30 canals and construction of 33 dams. The project was to interlink 14 northern Himalayan rivers to the 16 southern peninsular rivers. The purpose was that waters from the former surplus river basins be transferred to the later deficit river basins. Bengal opposed the project on the grounds that, on one side, it would increase flooding in Bangladesh and, on the other, aggravate the dry season ultimately affecting 100 million Bengalis life and 80 percent rice crop of Bengali farmers (Khalid, 2010). Bangladesh further argued that the National Water Linking Project (NRLP) is against 2004 Berlin rules of international water law. Indian side, on the contrary, defended the project on the plea that instead of aggravating, it would decrease the chances of flooding and droughts. Additionally, India argued that it would 
increase navigation and was a source of hydropower generation.

\subsection{Tipaimukh Dam}

Tipaimukh Dam is a 1500 MW Indian project to facilitate the Indian state of Assam. The project is on river Surma which provided seven percent fresh water to Bangladesh. The Bangladesh government charged against the dam on the basis that the project would halt volume of water from Surma and Kushera rivers in Bangladesh. Bangladesh feared that the dam would also adversely affect the ecosystem, irrigation and fishing downstream. A recent study conducted in the context of Tipaimuckh Dam by Huda suggested that the co-riparian should approach the dam from "a cooperative security angle," instead of the historical "sovereignty-based approach" an approach the researcher had found in the overall hydro politics of South Asia (Khalid, 2010).

\section{India-Nepal Water Disputes}

Nepal is the upper co-riparian of India. Though Nepal constitutes only four percent of the Ganges basin area, yet, its four main rivers, the Mahakali, Koshi, Gandak and Karnali-along with five minor tributaries, the Babai, Bagmati, Kamala, West Rapti, and Kankai, provides 71 percent of the glacial-fed waters and 47 percent of overall water flow of the Ganges basin. Nepal and India reached different treaties to manage their water resources, however, most of them remained controversial.

\subsection{The Gandak Agreement}

The Gandak river originates from Tibet, drains Nepal and Uttar Pradesh state of India and then flows into the Ganges. To control its flooding, utilise its waters for irrigation and generate electricity, India and Nepal signed the Gandak Agreement in 1959. The treaty suggested construction of a dam for the said purposes on this river. The dam lies in Nepal but is too close to the Indian border. Nepal considered the treaty unfair and complained that the water requirement of the project set under article 9 of the treaty was so excessive that sometimes the actual flow of the river decreased than the limit set. As a consequence, no substantial amount of water was left to be utilised for irrigation in Nepal. The treaty was revised in April 1964. However, the treaty still restricted Nepalese utility of river Gandak and the government of Nepal wanted to further revise the treaty in its favour.

\subsection{Koshi Treaty}

River Koshi is the largest river of Nepal that originates from Tibet and flows through Kathmandu and then reaches the Indian state of Bihar. To control flooding, utilise its water for irrigation and hydel purposes, the Koshi Treaty was concluded in 1954. The treaty provided for the construction of a dam on the river, straddling the border of Nepal and India which was completed in 1963. However, this treaty too was criticised by Nepal on the same ground as the Gandak Agreement and was revised in December 1966. Despite its revision, Nepal was unhappy with it and wanted further revision in its favour.

\subsection{The Mahakali Treaty}

The governments of India and Nepal signed a historic Mahakali Treaty on $12^{\text {th }}$ February 1996 
which came into force on $5^{\text {th }}$ June 1997 for the water management of the Mahakali River. The Mahakali River, known as Sarada in India, is the boundary line between India and Nepal. The treaty provided for the construction of a new multi-purpose dam under the Pancheshwar Multipurpose Project (PMP). PMP regulated the power allocation from already existing barrages of the Sarada which was built in 1920 and the Tanakpur which was built in 1992. The treaty's principles regarding the use of the river water included an equitable and reasonable utilisation of the water, equitable distribution of the benefits, and no significant harm to the parties. However, since the principles were general and less clear, especially the terminologies of "no significant harm", and "adverse effect" were unclear, the treaty held potential for mutual disputes (Uprety \& Salman, 2011).

The Mahakali Treaty also established a Mahakali River Commission with specified composition and functions. The commission was to be composed of equal members from both the states with specified functions such as exchange of information, inspection and governance of the projects and help in the differences and interpretation of the treaty. Similarly, the treaty also facilitated the parties with a dispute resolution mechanism. If the Mahakali River Commission failed to resolve a dispute, then the dispute was to be referred to an arbitrational tribunal. The decision of the tribunal was to be final. Mahakali Treaty with such an elaborate mechanism of arbitration like the IWT gives it the outward trapping of a good treaty. However, Nepal is unhappy with the Treaty and considered it unfair (Shrestha et al., 2012). Happiness or unhappiness of parties to a treaty is the litmus test of a treaty between nations. Measured by this criteria Nepal is unhappy with all the stated treaties. The dominant reason is that instead of assuaging mutual hydro-apprehensions, all the aforementioned treaties have resulted in stress in the India-Nepal water relations (Scott et al., 2019).

\subsection{Flooding}

Being the upper riparian, Nepal has been often criticised by the Indian government for being responsible for the downstream flooding and its subsequent devastation it inflicted on the population, infrastructure and other material in India. Nepal claimed these claims as baseless on the ground that Nepal did not have any storage capacity to withhold and release waters abruptly. Nepal further stated that the downstream flooding happened due to the climate change induced glacial lake outbursts.

\subsection{The Dispute of Kalapani}

India and Nepal disputed over the $75 \mathrm{~km}^{2}$ area of Kalapani. The territory of Kalapani was occupied by India in Sino-Indian War of 1962 and is of great strategic importance as the borders of India, Nepal and China meet there. The main point of dispute is the source of the Mahakali river. The Kalapani river borders the Mahakali's Nepalese zone. India claimed the Lipulekh located on the east of the Kalapani as the source, whereas Nepal claimed the Limpiyadhura situated on the west of Kalapani to be the source of the Mahakali River. It was this claim of the source of the river that made the area of Kalapani disputed (Khalid, 2010). Since 1997, several rounds of India-Nepal negotiations could hatch no solution.

\subsection{Nepal's Proposed Hydropower Projects}

Nepal has a huge potential for hydro Power generation which is estimated at $83280 \mathrm{MW}$. Its present installed capacity is $250 \mathrm{MW}$ which is only 0.3 percent of the total estimated potential. 
Nepal wanted to exploit this potential and construct dams for the said purpose, but India resisted it on the grounds that the proposed Nepalese dams would have serious agricultural, flood related and strategic implications for downstream India. Various recent studies recommended different multi-purpose projects but the same could not be materialised due to India-Nepal disagreements in this regard.

\section{India-Bhutan Water Management}

Bhutan is a landlocked country and is located on the high ranges of Himalaya. The country remained inaccessible to the rest of the world till 1960 when it initiated its first developmental plan a year later. Due to mountainous location its agriculture is nominal. However, due to its water resources coupled with mountainous terrain, its hydro power potential is estimated at 20,000 MW (Biswas, 2011). To exploit its hydro potential, it ventured a plan, the Wangchu Cascade at Chukha, in cooperation with India in 1980. It's a $336 \mathrm{MW}$ project for which India provided assistance on the basis of $60 \%$ grant and $40 \%$ loan. The project was a success as it covered its cost by 1993. Due to its success, the project was later upgraded to $370 \mathrm{MW}$. According to the agreement the electricity generated was first to fulfil the Bhutanese needs and only then the extra electricity was sold to the Indian government. Following this project, India and Bhutan initiated other joint hydel power projects as the $45 \mathrm{MW}$ Kuri Chu project, the 1020 MW Chukka-II and the 900 MW Chukka-III project are agreed upon. Similarly, in 1993, to study the feasibility of a large dam on river Sunkosh an agreement has also been signed.

As compared to Bangladesh and Nepal, India and Bhutan have been successful in cooperative management of the rivers especially in the hydro-power sector. This cooperation between India and Bhutan is not exploitative for any of the riparian but benefited both the nations (Williams, 2018). The revenue which the hydro power generates is of vital importance for the economic viability of Bhutan. According to estimates, 60 percent of its national GDP is generated from the sale of its hydropower to India (Shah \& Shah, 2013). This win-win approach by India and Bhutan is a good example in the regional water cooperation. Due to this approach, Bhutan's per capita GDP has spiralled up from one of the lowest in the region in 1980 to the highest at US\$ 1932.8 in 2008 (Biswas, 2011).

\section{Pakistan-Afghanistan Water Crisis}

Pakistan and Afghanistan are co-riparian on River Kabul. 23 Percent of the population of Afghanistan lives in the Kabul river basin which extends over nine Afghan provinces. Downstream Pakistan had raised its concerns over Afghan government's unilateral initiative to tap into the potential of River Kabul. However, it was in 2014 when Pakistan's fears heightened when the Afghan government announced to initiate construction of many dams on the River Kabul and its tributaries. One of the reasons was the Indian assistance in this regard. Pakistan believes that India is assisting Afghanistan with 12 dams many of which are located on the River Kabul including the Shahtoot and the Sharooz. Pakistan sees the Indian assistance to Afghanistan in this regard as "an extension of Indian hydro-hegemony from Kashmir to Kabul." However, India argues that the war-ravaged country of Afghanistan was in need of the proposed storage facilities and India was extending assistance to a fellow regional state (Bakshi \& Trivedi, 2011). Pakistan fears that any Afghan taming of River Kabul will affect its own downstream 250-MW Warsak Dam including the Warsak Canal System and Kabul River Canal System which irrigates the vast fertile lands of Peshawar valley. 
Similar charges are levelled by Afghanistan against Pakistan which is upper riparian to an important tributary of the River Kabul called River Chitral. It is alleged that Pakistan is unilaterally constructing its own series of dams on River Chitral which has downstream effects in the Kunar province of Afghanistan. In addition to River Kabul, some other important rivers which flow from Afghanistan into Pakistan have potential to generate future tensions between the two riparians. These rivers include River Gomal, River Tochi, and River Kurram which irrigate the vast lands of southern part of Khyber Pakhtunkhwa, Pakistan. In case Afghanistan pursued its efforts of constructing dams on River Kabul either with or without the Indian or the World Bank's assistance, it may not only result in water crisis between Afghanistan and Pakistan but may become a security issue between India and Pakistan as well. A recent work on this fact has elaborated the issue as "The decision of Afghan government to construct a dam on the River Kabul through financial support of India did not go down well with Pakistan. The increasing Indian involvement in Afghanistan is seen by Pakistan as a threat to its national security. The Kabul (river) is an important tributary of Indus (river) which contributes 20-28 MAF to the river flows. The supplied water is indispensable for fulfilling the water demands of Khyber Pakhtunkhwa province of Pakistan" (Qamar et al., 2019).

\section{Conclusion}

The governments of India have not only failed to adopt a conciliatory approach towards Pakistan on the Indus rivers but has also generated a mistrust amongst other co-riparians, Bangladesh and Nepal. India's penchant for bilateralism, repeated reliance on adhoc arrangements to escape binding and permanent agreements, especially multilateral ones, manipulation of already agreed water treaties, make the legitimate water quests of its coriparian elusive. Such a hydro-behaviour towards its riparian represented the behaviour of a regional hydro-hegemon which revealed the same gloomy picture for the entire IndusBrahmaputra-Ganges-Meghna rivers system what John Briscoe had predicted for the Indus in 2010. The India-centric water disputes and the accompanying stresses and strain in the respective treaties owed much to the Indian hydro-hegemonic designs which is based on the asymmetric distribution of power in the region.

India-Bhutan cooperation in the water sector is a role model for the region. India can extend the same conciliatory approach towards its other smaller co-riparian states. The India-Afghan cooperation is also laudable. However, if such an assistance is power-oriented, then it is a bad omen for the security of the region. To unite the regional states into the unity all the four rivers provide, India has to behave like the saintly Ganga instead of an Orwellian Big Brother. India is at the centre of the region and has to initiate the change towards a better policy based on mutual accommodation. In the words of John Briscoe, "the regional hegemon is the upper riparian and has all the cards in its hands. This asymmetry means that it is India that is driving the train, and that change must start in India" (Briscoe, 2010). For such a change, Briscoe suggested the mind-set of Nelson Mandela. He raised an inspiring question to the close of his article as; "Who will be the Indian Mandela who will do this?"

\section{References}

Amir, P. \& Habib, Z. (2015). Estimating the impacts of climate change on sectoral water demand in Pakistan. ACT Report. https://cyphynets.lums.edu.pk/images/Readings_concluding.pdf 
Bakshi, G., \& Trivedi, S. (2011). The Indus equation. Strategic Foresight.

Bhatti, M. N. (2020). Politics of water resource management in the Indus river basin: a study of the partition of Punjab. Liberal Arts \& Social Sciences International Journal (LASSIJ), 4(2), 60-70. https://doi.org/10.47264/idea.lassij/4.2.6

Biswas, A. K. (2011). Cooperation or conflict in transboundary water management: case study of South Asia. Hydrological Sciences Journal, 56(4), 662-670. https://doi.org/10.1080/02626667.2011.572886

Briscoe, J. (2010, April 3). War or peace on the Indus? The News International. https://johnbriscoe.seas.harvard.edu/files/johnbriscoe/files/108. john_briscoe_war_ or_peace_on_the_indus_201004.pdf

Buis, A. \& Wilson, J. (2015). Study: third of big groundwater basins in distress. https://www.nasa.gov/jpl/grace/study-third-of-big-groundwater-basins-in-distress/

Cohen, S. P. (2005, January). The US and South Asia. Seminar, No. 545. https://www.brookings.edu/wp-content/uploads/2016/06/20050101.pdf

Gardner, K. (2019). Moving watersheds, borderless maps, and imperial geography in India's Northwestern Himalaya. The Historical Journal, 62(1), 149-170. https://doi.org/10.1017/S0018246X18000146

Gulhati, N. D. (1973). Indus waters treaty: an exercise in international mediation. Allied.

Huda, M. S. (2017). Envisioning the future of cooperation on common rivers in South Asia: a cooperative security approach by Bangladesh and India to the Tipaimukh Dam. Water International, 1(42), 54-72. https://doi.org/10.1080/02508060.2016.1236232

Indus Waters Treaty (1960, September 19). International water law. https://www.internationalwaterlaw.org/documents/regionaldocs/IndusWatersTreaty 1960.pdf

Jayaram, D. (2016). Why India and Pakistan need to review the Indus waters treaty. https://www.climate-diplomacy.org/news/why-india-and-pakistan-need-reviewindus-waters-treaty

Khalid, I. (2010). Trans-boundary water sharing issues: a case of South Asia. Journal of Political Studies, $\quad 1(2), \quad 79-96$. https://search.proquest.com/openview/4bf372ca0034481ba2924713b8f4cefb/1?pqorigsite $=$ gscholar\&cbl $=237375$

Kugelman, M. (2016). Why the India-Pakistan war over water is so dangerous. Foreign Policy. https://foreignpolicy.com/2016/09/30/why-the-india-pakistan-war-over-water-is-sodangerous-indus-waters-treaty/

Lilienthal, D. E. (1951, August 4). Another "Korea" in the making? Collier's. https://doi.org/10.1002/wwp2.12035

Pohl, B. \& Schmeier, S. (2014). Hydro-diplomacy can build peace over shared waters, but needs more support. https://www.newsecuritybeat.org/2014/09/hydro-diplomacybuilds-peace-shared-waters-support/

Qamar, M. U., Azmat, M., \& Claps, P. (2019). Pitfalls in transboundary Indus water treaty: a perspective to prevent unattended threats to the global security. NPJ Clean Water, 2 (22). https://doi.org/10.1038/s41545-019-0046-X.

Scott, C. A., Zhang, F., Mukherji, A., Immerzeel, W., Mustafa, D., \& Bharati, L. (2019). Water in the Hindu Kush Himalaya. In Wester, P., Mishra, A., Mukherji, A., and Shrestha, A. B. The Hindu Kush Himalaya. 257-299. Springer. https://www.springer.com/gp/book/9783319922874

Shah, R. D. T., \& Shah, D. N. (2013). Evaluation of benthic macroinvertebrate assemblage for disturbance zonation in urban rivers using multivariate analysis: implications for river 
management. Journal of Earth System Science, 122 (4), 1125-1139. https://doi.org/10.1007/s12040-013-0317-8

Sharif, N. (2008). Crossed swords: Pakistan, its army, and the wars within. Oxford University.

Shrestha, R. K., Ahlers, R., Bakker, M., \& Gupta, J. (2012). Institutional dysfunction and challenges in flood control: a case study of the Kosi flood 2008. Economic and Political Weekly, 2, 45-53. https://www.epw.in/journal/2010/02/specialarticles/institutional-dysfunction-and-challenges-flood-control-case-study

Sood, A. \& Mathukumalli, B.K.P. (2011). Managing international river basins: reviewing India-Bangladesh transboundary water issues. International Journal of River Basin Management, 9(1), 43-52. https://doi.org/10.1080/15715124.2011.553832

Uprety, K., \& Salman., S. M. A. (2011). Legal aspects of sharing and management of transboundary waters in South Asia: preventing conflicts and promoting cooperation. Hydrological Sciences Journal, 56(4), 641-661. https://doi.org/10.1080/02626667.2011.576252

Wasi, N. (2009, September). Harnessing the Indus waters: perspectives from Pakistan. IPCS Issue Brief 128. New Delhi: Institute of Peace and Conflict Studies (IPCS). http://www.ipcs.org/issue briefs/issue brief_pdf/IB128-Ploughshares-Nausheen.pdf Williams, J. M. (2018). Stagnant rivers: transboundary water security in South and Southeast Asia. Water, 10(12), 1819. https://doi.org/10.3390/w10121819 